Western University Scholarship@Western

1998

\title{
Housing Taxation and Capital Accumulation
}

Martin Gervais

Follow this and additional works at: https://ir.lib.uwo.ca/economicsresrpt

Part of the Economics Commons

Citation of this paper:

Gervais, Martin. "Housing Taxation and Capital Accumulation." Department of Economics Research Reports, 9807. London, ON: Department of Economics, University of Western Ontario (1998). 
ISSN:0318-725X

ISBN:0-7714-2103-6

\title{
RESEARCH REPORT 9807
}

\section{Housing Taxation and Capital Accumulation}

ECOHORAS REFERNE CERTE

by

Martin Gervais

JUN 301998

UNAVRSTYY OF WESTERH ERTTARIO

June 1998

\author{
Department of Economics \\ Social Science Centre \\ University of Western Ontario \\ London, Ontario, Canada \\ N6A 5C2 \\ econref@sscl.uwo.ca
}




\title{
Housing Taxation and Capital Accumulation
}

\author{
Martin Gervais * \\ The University of Western Ontario \\ Department of Economics \\ London, Canada N6A $5 \mathrm{C} 2$ \\ gervais@sscl.uwo.ca
}

June 19, 1998

\begin{abstract}
This paper studies the impact of the preferential tax treatment of housing capital in a model economy that includes the main housing tax provisions currently in place in the U.S. and a minimum downpayment requirement upon purchasing non-divisible houses. Distortions arise because the tax code makes the return on housing capital larger than that on business capital. The wedge between the two rates of return emanates from the failure to tax imputed rents and is amplified by the presence of mortgage interest deductibility: Simulations show that either taxing imputed rents or eliminating mortgage interest deductibility substantially increases welfare. . Moreover. welfare gains accrue to individuals at every income level and distributional effects are much smaller than conventionally believed. (JEL E62. H3)
\end{abstract}

\footnotetext{
-I am grateful to Andres Erosa. Ig Horstmann and David Laidler for the generous use of their time and constant encouragement. For their comments and suggestions. I would like to thank Jim Davies. Al Slivinski and Gustavo Ventura. as well as seminar participants at the University of Vaterloo and the CEA meetings in St. John's (1997). Financial support from The Bradley Foundation is gratefully acknowledged.
} 


\section{Introduction}

It has long been understood that housing capital receives preferential tax treatment relative to other types of capital in the U.S.. The two most important housing tax advantages are that the service income provided by owner-occupied housing (generally referred to as imputed rents) is untaxed and mortgage interest payments are deductible from taxable income (Rosen, 1985). The potential distortions caused by this asymmetric treatment of different sources of capital income are substantial, especially in light of the fact that housing capital, broadly defined, accounts for well over 50 percent of the capital stock in the U.S. (Diaz-Giménez et al., 1993). The object of this study is to quantitatively assess the impact of this preferential tax treatment on the composition of the aggregate stock of capital and estimate its welfare and distributional effects.

This study emphasizes two channels through which housing tax provisions distort individuals: behavior. One is that the tax code provides an incentive for individuals to own rather than rent. The other is that, should they own, individuals have an incentive to own larger houses. In both cases, these distortions are due to the fact that the tax code makes the return on housing capital larger than that on business capital. The wedge between the two rates of return arises from the failure to tax implicit rental income from owner-occupied housing. The presence of mortgage interest deductibility, although neither sufficient nor necessary for the existence of a wedge between the two rates of return. increases the size of the wedge.

The impact of these tax provisions is analyzed in a general equilibrium life-cycle economy populated by heterogenous individuals. Individuals consume housing services by either renting or owning a house. If they own. there is a minimum size house that can be purchased and a downpayment is required. The tax code in the model allows for differential taxation of owner-occupied housing and other forms of capital income. It also allows for a fraction of mortgage interest payments to be deducted from taxable income. The benchmark model 
is calibrated to the U.S. economy where imputed rents are not taxed and individuals have the ability to fully deduct mortgage interest payments from taxable income. The model is then used to compare alternative fiscal policy arrangements. ${ }^{1}$

Simulations show that taxing imputed rents at the same rate as business capital income increases the stock of business capital by over 6 percent and decreases the stock of housing capital by more than 8 percent, lending support to the view that the current tax structure causes housing to crowd out business capital. ${ }^{2}$ This tax change also has a considerable impact on the homeownership rate as approximately one quarter of homeowners in the benchmark specification change their tenure choice when imputed rents are taxed. The elimination of mortgage interest deductibility delays individuals' decision to buy a house, increasing the rental housing stock at the expense of owner-occupied housing. The level of total housing capital. however, is unaffected by the elimination of this program. The long run welfare gains of disallowing mortgage interest deductions and taxing imputed rents are estimated to be approximately one and four percent of average life-time consumption. respectively. Moreover. welfare gains accrue to individuals across the income distribution in both experiments. Contrary to conventional wisdom. either disallowing mortgage interest deductions or taxing imputed rents has very small distributional effects in the long run. ${ }^{3}$

At the root of these findings is the size of the wedge that tax policies create between the rates of return on owner-occupied housing and business capital. This wedge affects individuals' decisions in two ways. First. it distorts the tenure choice by providing an incentive for individuals to become homeowners. Since doing so entails a sizable downpayment. individu-

\footnotetext{
${ }^{1}$ Rosen (1985) reports that 96.2 percent of government revenue losses from the special tax treatment of housing emanates from owner-occupied housing. Fullerton (1987) estimates the effective tax rate on owner-occupied housing to be 19 percent while his estimate on the tax rate on non-housing capital is 36 percent. These figures become -5 and 25 percent. respectively, when property taxes are regarded as a fee for government services.

${ }^{2}$ Other studies consistent with a crowding out effect include Feldstein (1982). Hendershott and Hu (1983). Gahvari (1984) and Poterba (1984).

${ }^{3}$ It is usually argued that because homeownership rates differ considerably across groups of different status, changes in the relative tax treatment of owner-occupied housing versus rental units have important distributional effects. See Poterba (1990) for a discussion of this view.
} 
als strive to accumulate savings quickly in order to afford to own a house. The extra savings necessary to become a homeowner implies a substitution of consumption when young for future consumption. Second, when the return on owner-occupied housing dominates that on other assets, homeowners have an incentive to hold a high fraction of their wealth in the form of housing capital. Consequently, homeowners spend an excessive fraction of their total expenditures on housing services. While the elimination of mortgage interest deductibility reduces the distortion associated with excessive savings, taxing imputed rents eliminates this distortion as well as the distortion to the composition of savings.

This study is by no means the first to assess the impact of the federal tax treatment of housing. The most robust result in this literature is that the preferential tax treatment of housing induces homeowners to over-consume housing services. This effect. which is also strong in this study, has been shown to be important both in static (Laidler, 1969, Poterba 1984 and 1992, Berkovec and Fullerton. 1992) and dynamic models (Gahvari. 1984. Skinner, 1996). ${ }^{4}$ An important omission common to all these studies is the lack of an explicit tenure decision. ${ }^{5}$ This paper argues that the interaction between the tax code and the tenure choice is an essential channel through which housing tax provisions distort individuals: decisions over time. This finding is consistent with Engelhardt's (1996) empirical analysis. which suggests that borrowing constraints in the housing market cause individuals to experience high growth rates of consumption once they become homeowners. ${ }^{6}$ In addition to capturing this effect on individuals lifetime consumption profile. endogenizing the tenure decision between renting and owning allows me to investigate distributional issues. ${ }^{\top}$

\footnotetext{
${ }^{t}$ Skinner assumes a tixed housing stock. However. the preferential tax treatment of housing raises the price of housing capital. Consequently a large fraction of the value of individuals' savings takes the form of housing capital. The value of housing services consumed is equally high.

'Berkovec and Fullerton is an exception. The interaction between the tenure choice and the tax code. however. is limited by the static nature if their model. This lack of dynamic effects leads these authors to conclude that eliminating mortgage interest deductibility has very little impact. An interesting finding in this study is that taxing imputed rents is welfare improving partly because it allows the government to pool some of the risk associated with owner-occupied housing.

${ }^{6}$ This argument was formally made by Artle and Varaiva (1978).

'For an interesting model with a non-trivial tenure choice do to externalities in the rental inarket. see
} 
The rest of the paper is organized as follows. The model economy is presented in section 2. Section 3 develops some intuition on how specific features of the tax code interact with the tenure choice, financing and savings decisions of individuals. In section 4 , the benchmark model is calibrated to the U.S. economy. Two simulations are performed and discussed in sections 5 . The first experiment assesses the impact of removing mortgage interest deductibility. In the second experiment, the impact of setting the tax rate on implicit rental income equal to the rate of taxation of business capital income is analyzed. A brief summary concludes the paper.

\section{Model Economy}

I investigate a general equilibrium life-cycle economy populated by heterogenous agents. The model follows the line of research initiated by Auerbach and Kotlikoff (1987) in studying fiscal policy in life-cycle economies. The main differences stem from the focus of this paper on different sources of capital income taxation. The capital stock is disaggregated into business capital and housing capital. the latter being defined as durable goods plus housing. The special properties of housing capital are modeled explicitly by including the most important features of its tax-treatment as well as a downpayment constraint upon the purchase of such capital.

\subsection{Households}

Preferences The economy is populated by overlapping generations of individuals with finite lives. Individuals derive utility from a composite consumption good and housing

Henderson and Ioannides (1983). 
services. The utility function of a new born individual is given by

$$
\sum_{j=1}^{J} \beta^{j-1}\left(\log c_{j}+\theta \log x_{j}\right), \quad 0<\beta<1
$$

where $c_{j}$ and $x_{j}$ respectively denote consumption of composite goods and housing services of an age- $j$ individual. $\beta$ is the time-discount factor, and $J$ is individuals' lifetime. The technology for deriving housing services is discussed next.

Housing Capital and Housing Services Individuals can either own or rent. Homeowners obtain housing services directly from their housing capital. I assume that one unit of housing capital generates one unit of services, $x_{j}=h_{j}$, where $h_{j}$ represents housing capital held by an age- $j$ individual. In order to purchase a house. an individual must make a downpayment. ${ }^{8}$ The minimum downpayment required is given by a fraction $\gamma$ of the value of the house. The remaining cost can be financed by borrowing against the house. The amount borrowed, the mortgage, is denoted $b_{j}$. The fraction $\gamma$ thus represents the smallest equity fraction an individual can hold in a house, with $(1-\gamma)$ giving the maximum loan-to-value ratio. In order for the downpayment requirement to potentially constrain individuals in their purchase of a home. it is assumed that housing capital is not perfectly divisible. This is modeled by assuming a minimum size of houses. This minimum size is given by $\underline{h}$ : which also represents the smallest amount of housing services a homeowner can consume.

As an alternative to purchasing a house. individuals can rent housing services. Renting housing services has two advantages over owning. First. it allows individuals to consume housing services while avoiding the downpayment requirement. Second. rental accommodations are not subject the same indivisibility as owner-occupied housing. Relatively poor individuals. who want to consume small amounts of housing services. can do so by sharing

\footnotetext{
${ }^{8}$ Stein (1995) illustrates that a downpayment requirement can arise endogenously in response to adverse selection problems. In some countries. the government exogenously imposes a downpayment fraction (see
Jappelli and Pagano. 1994).
} 
rental accommodations. This feature is captured by allowing up to $M$ individuals to receive services from a given stock of housing capital. The smallest amount of housing services a renter can consume is thus given by $\underline{h} / M$. Rented housing services are subsequently denoted $s_{j}$.

Total housing services are simply the sum of rented and derived housing services, $x_{j}=$ $s_{j}+h_{j}$. Under this specification, renting and owning are perfect substitutes in consumption. The price of one unit of housing services in terms of consumption goods is denoted $p$.

All housing capital depreciates at a per period rate of $\delta_{h}$ units per unit of capital. Equivalently, homeowners incur a maintenance cost equal to the amount of depreciation in the period during which the house is owner-occupied. thus preventing the house from depreciating. The latter convention ensures that homeowners cannot let their house depreciate below the minimum size house.

Income Dynamics The life of each individual consists of a working stage and a retirement period. These stages are separated by an exogenously given mandatory retirement age. In each period of their working lives. individuals are endowed with one unit of working time which they supply inelastically. An age- $j$ individual's unit of working time is transformed into $z_{j}$ units of labor input. where $z_{j} \in Z_{j}$ is an exogenously given productivity level distributed according to $F_{j}\left(z_{j}\right)$. Each unit of effective labor is paid the wage rate $w$. This specification allows for individuals to differ both across and within generations. At any point in time. the average productivity level (of the working population) is fixed at unity. The measure of the entire population is also normalized at unity.

In addition to labor income. individuals receive income through their asset holdings. Individuals accumulate wealth both for lice-cycle reasons (there are no government pensions) and to meet the downpayment required for the purchase of a house. Individuals have access to three assets to accumulate wealth: housing (net of mortgages), business capital equity: and deposits at financial institutions. Loans are only available to homeowners in the form 
of mortgages, and are restricted by the downpayment constraint.

From a household's perspective, deposits at financial institutions and business capital equity are equivalent. A no-arbitrage condition guarantees that the rate of return on these assets is equalized. As a result, the sum of deposits at financial institutions and business capital equity constitute a single financial asset, denoted $a_{j}$. The balance sheet of an age- $j$ individual takes the following form:

Table 1: Household's Balance Sheet

\begin{tabular}{l|l}
\hline \hline \multicolumn{1}{c}{ Assets } & \multicolumn{1}{c}{ Liabilities } \\
\hline Owner-Occupied Housing $\left(h_{j}\right)$ & Mortgage $\left(b_{j}\right)$ \\
Financial Assets $\left(a_{j}\right)\left\{\begin{array}{l}\text { Deposits } \\
\text { Capital Equity }\end{array}\right.$ & Net Worth $\left(y_{j}=a_{j}+h_{j}-b_{j}\right)$ \\
\hline \hline
\end{tabular}

\subsection{Financial Institutions}

The role of financial institutions is to pool individuals' deposits in order to finance loans issued to homeowners and purchase residential capital. Financial institutions use the same linear technology as homeowners to produce housing services. which they rent out to individuals who do not own a house.

Financial institutions are introduced in the model solely to simplify the exposition. With all borrowing and lending being intermediated and all rental housing units being owned by financial institutions. the housing stock held by individuals corresponds to owner-occupied housing. In other words. there is no need to keep track of the proportion of owner-occupied housing in individuals housing capital. 


\subsection{Technology - Goods Producing Sector}

Output is produced using a Cobb-Douglas production technology

$$
f(K, N)=A K^{\alpha} N^{1-\alpha},
$$

where $A$ is a technology parameter, $K$ is the total (or per capita) amount of business capital used in production and $N$ represents the size (or measure) of the working population. Each period the business capital stock depreciates at rate $\delta_{k}$. Output goods can be costlessly transformed into consumption goods, residential investment (and maintenance) goods, or business investment goods. Accordingly, the price of both types of investment goods will be equal to the price of the consumption good. which is normalized at unity.

\subsection{Structure of Taxation}

Individuals earn labor income and two types of capital income. The two sources of capital income are: (i) financial assets, which generate the usual interest income. and (ii) housing capital. which generates income in the form of imputed rents. The tax code in the model allows for all three sources of income to be taxed. In addition. the tax code allows for any fraction of mortgage interest payments to be deducted from taxable income. A fiscal policy arrangement involves three parameters $\left\{\tau_{y}, \tau_{i r} \tau_{i n}\right\}$. where $\tau_{y}$ is a proportional tax rate on labor income and the return on financial assets. $\tau_{i r}$ denotes the rate of taxation on imputed rents. and $\tau_{m}$ is the fraction of mortgage interest payments that can be deducted from taxable income. ${ }^{9}$

As is the case in the U.S. tax code. mortgage interest payments are deductible against taxable income rather than the revenues generated by the asset against which the loan

\footnotetext{
"It is worth noting that in 1993. imputed rents were taxed in 9 of the 24 OECD countries. In the same year. 5 of the 24 countries did not allow mortgage interest payments to be deductible. (Taxation and
Household Saving, OECD. 1994)
} 
is secured. I restrict the extent of mortgage interest deductibility to make the deduction at least as large as the "normal" deduction, defined as the deduction that would result if mortgage interest payments were in fact deductible against housing capital revenues instead of other types of income. In order to guarantee at least the normal deduction, the extent of mortgage interest deductibility is restricted throughout the rest of the paper by the following inequality: $\tau_{m} \geq \tau_{i r} / \tau_{y} \cdot{ }^{10}$ The set of feasible fiscal policy arrangements, then, is given by $\Omega=\left\{\left\{\tau_{y}, \tau_{i r}, \tau_{m}\right\}: \tau_{m} \geq \tau_{i r} / \tau_{y}, 0 \leq \tau_{y}, \tau_{i r}, \tau_{m} \leq 1\right\}$.

Each period the entire proceed from taxation is used to finance government expenditures, which do not affect individuals at the margin. The government thus maintains a balanced budget every period.

\subsection{Household's Decision Problem}

The household problem can be broken down into intra-period and intertemporal decisions. The intertemporal decision consists of choosing the amount of savings to carry over to the next period. Once the intertemporal decision is made. households choose the amount of composite goods and housing services to consume during the current period. as well as the composition of savings carried over from the previous period.

The simplicity of the problem derives from the fict that only one state variable is needed to describe the situation of an age- $j$ individual with productivity level $z_{j}$. This state variable is today's net worth. or alternatively yesterday's savings. Without uncertainty, the composition of today's savings between different assets is irrelevant since the same composition will result whether the decision is made today or tomorrow. Hence the only information needed as an individual enters a period is the total amount of savings carried over from the previous period. as opposed its composition between financial assets. housing

\footnotetext{
${ }^{10}$ The deduction in the model is given by $\tau_{m} \tau_{y} i b$. L ising a no-arbitrage from the financial institutions: problem (see equation (10)), the normal deduction is equal to $\tau_{i r} i b$. Hence $\tau_{m} \geq \tau_{i r} / \tau_{y}$ guarantees that the deduction in the model is at least as large as the normal deduction.
} 
and mortgages. In other words, today's amount of savings is chosen knowing that its composition will be optimized tomorrow.

These points become obvious in the recursive formulation of the households' problem. Let $V_{j}\left(y_{j} ; z_{j}\right)$ denote the value of behaving optimally from period $j$ until period $J$ for an individual who enters period $j$ with net worth $y_{j}$ and productivity level $z_{j}$. Given a net worth position at age $j$, a household chooses next period's net worth to maximize total future discounted utility. The value function of an age $-j$ individual is defined as

$$
V_{j}\left(y_{j} ; z_{j}\right) \equiv \max _{y_{j+1} \in \Gamma}\left\{G_{j}\left(y_{j}, y_{j+1} ; z_{j}\right)+\beta V_{j+1}\left(y_{j+1} ; z_{j+1}\right)\right\}
$$

where $\Gamma$ is the feasible set from which tomorrow's net worth is chosen. The return function of an age- $j$ individual, $G_{j}$, is defined as the maximum utility level a household can achieve given today's and tomorrow's level of net worth. In other words, the return function is that which solves the following intra-temporal problem:

$$
G_{j}\left(y_{j}, y_{j+1} ; z_{j}\right) \equiv \max _{\left\{c_{j}, x_{j}, a_{j}, h_{j}, b_{j}\right\}}\left\{\ln c_{j}+\theta \ln x_{j}\right\}
$$

subject to

1. budget constraint

$$
c_{j}+p x_{j}+y_{j+1} \leq\left(1-\tau_{y}\right) z_{j} w+y_{j}+\left(1-\tau_{i r}\right)\left(p-i_{h}\right) h_{j}+\left(1-\tau_{y}\right) i a_{j}-\left(1-\tau_{y} \tau_{m}\right) i b_{j}
$$

where

$$
\begin{aligned}
& y_{j}=a_{j}+h_{j}-b_{j} \\
& x_{j}=s_{j}+h_{j}
\end{aligned}
$$




\section{2. housing constraints}

$$
\begin{aligned}
h_{j} & \geq \underline{h}, \\
s_{j} & \geq \underline{h} / M,
\end{aligned}
$$

3. net worth constraints

$$
\begin{aligned}
& y_{j} \geq \gamma h_{j}, \\
& y_{j} \geq h_{j}-b_{j},
\end{aligned}
$$

4. and

$$
\begin{gathered}
c_{j} \geq 0, j=1,2, \ldots J, \\
z_{j}=0, j \geq j^{*}, \\
a_{1}=h_{1}=0 .
\end{gathered}
$$

The left hand side of the budget constraint (3) includes expenditures on consumption goods and housing services. as well as the total amount of savings carried over to the next period. The revenue side includes labor income net of income taxes. after-tax implicit rental income (net of depreciation) from owner-occupied housing, after-tax income from financial assets. minus mortgage payment net of deductibility. It is interesting to note that when imputed rents are not taxed $\left(\tau_{i r}=0\right)$. housing services do not appear in homeowners budget constraint. In essence. homeowners simply transfer money from one pocket to the other to pay themselves the rent.

The two housing constraints are self explanatory, but the net worth constraints require some explanation. The first net worth constraint derives directly from the downpayment 
constraint. It says that a household's net worth cannot be smaller than the minimum amount of equity a household can hold in owner-occupied housing. The second net worth constraint is simply one way of imposing that financial assets be non-negative, $a_{j} \geq 0$.

\subsection{Financial Institutions' Decision Problem}

There are a variety of ways to formulate the financial institutions' problem. A simple one is to think of financial intermediaries as two-period lived institutions, with a new cohort being born every period. During the first period of their existence, financial institutions issue loans and buy residential capital using the proceeds from deposits they accept. During the second period, they receive payments for rental accommodations and interests on loans issued, and pay interests on deposits. They then sell the undepreciated part of their capital to new financial institutions.

Financial intermediaries pay the same interest rate $i$ on deposits as they charge on loans contracted with individuals. The problem of a new financial institution in period $t$ is as follows:

$$
\max _{\left\{B_{t+1}^{f}, \delta_{t+1}^{f}, H_{t+1}^{f}, D_{t+1}^{f}\right\}}\left(p S_{t+1}^{f}-\delta_{h} H_{t+1}^{f}+i B_{t+1}^{f}-i D_{t+1}^{f}\right)
$$

subject to

$$
\begin{aligned}
H_{t+1}^{f}+B_{t+1}^{f} & \leq D_{t+1}^{f} \\
S_{t+1}^{f} & \leq H_{t+1}^{f},
\end{aligned}
$$

where $H_{t}^{f}$ denotes the total amount of rental housing in period $t . D_{t}^{f}$ the total amount of deposits received. $B_{t}^{f}$ the total amount of loans issued to households. and $S_{t}^{f}$ the total 
amount of housing services provided by financial institutions.

For this maximization problem to be well defined, the following no-arbitrage condition has to be satisfied:

$$
i=p-\delta_{h}
$$

which indicates that financial institutions are at the margin indifferent between their asset holdings and liabilities. Clearly, financial institutions will make zero profits in equilibrium.

\subsection{Competitive Equilibrium}

A formal definition of a competitive equilibrium is given in the Appendix. As has become standard in the study of dynamic general equilibrium models, equilibria are obtained through numerical methods. The households' problem emphasizes the division of the problem into intra- and inter-temporal decisions on which the algorithm is based. In the next section. I use the intra-temporal problem to shed some light on the relation between the tax code and individual's tenure and financing decisions.

\section{Housing Tax Provisions and Owner-Occupied Benefits}

Individuals' intra-temporal problem is a static one that consists of choosing a consumption bundle and the composition of savings carried over from the previous period (or beginningof-period net worth), taking today's savings decision as given. When an individual's savings are not sufficient to meet the downpayment requirement. the tenure and financing decisions are straightforward: the individual rents. When savings are large enough that neither the minimum house size constraint (j) nor the net worth constraints (6) bind. then individuals prefer owning to renting as long as the tax rate on imputed rents is lower than the rate of 
taxation on other forms of capital income. It is interesting to note that the extent of mortgage interest deductibility does not influence the tenure decision as long as the deduction is no smaller than the normal deduction defined in the previous section. Instead, mortgage interest deductibility affects the decision on how the house purchase is funded. More precisely, individuals strictly prefer equity to debt whenever mortgage interest payments are not fully deductible.

The tax code also has dynamic effects on individuals' decisions. Given that an individual needs a large enough level of savings to take advantage of homeownership, the intertemporal decision problem is affected by housing tax policies. In particular. when the tax code makes owning a better alternative than renting, individuals strive to accumulate savings quickly in order to afford owning a house. The extra savings necessary to become a homeowner implies a substitution of consumption when young for future consumption. In addition, the preferential tax treatment of owner-occupied housing induces homeowners to over-consume housing services. The static and dynamic effects are discussed in details below.

\subsection{Tenure Choice and Financing Decision}

When an individual's savings are large enough that (5) and (6) do not bind. the net benefit from homeownership can be defined as the difference between the revenues homeownership provides minus the opportunity cost of owning. More precisely, let $h$ be the house size an individual would choose if renting were the only available option. and consider the benefit (or cost) associated with owner-occupying the same house. Given today's and tomorrow's net

worth. increasing the amount of owner-occupied housing by $h$ units increases an individual's income by $\left(1-\tau_{i r}\right)\left(p-\delta_{h}\right) h$. If borrowing is needed. that is. if $h>y$, then owning carries an interest payment net of deductibility equal to $\left(1-\tau_{y} \tau_{m}\right) i b$. Finally, the opportunity cost of investing in housing corresponds to the after-tax return from an investment of $(h-b)$ units in financial assets. which amounts to $\left(1-\tau_{y}\right) i(h-b)$. After some manipulations. 
and using the no-arbitrage condition from the financial institutions' problem (10), the net benefit from homeownership for a given policy arrangement $\omega \in \Omega$ can be written as

$$
\pi(h, b ; \omega)=\left[\left(1-\tau_{i r}\right) i h-\left(1-\tau_{y}\right) i h\right]-\left[\left(1-\tau_{y} \tau_{m}\right) i b-\left(1-\tau_{y}\right) i b\right]
$$

The term inside the first square brackets corresponds to the implicit rental income from owner-occupied housing minus the opportunity cost of holding the entire asset. I refer to this term as the asset benefit. The term inside the second square brackets includes the cost of borrowing and the opportunity cost of the borrowed funds. This term is referred to as the borrowing benefit or penalty.

It is clear from (11) that the asset benefit is always positive when imputed rents are taxed at a lower rate than other income. This benefit is simply equal to the amount of taxes saved by holding wealth in a non-taxable asset (housing) rather than a taxable one (financial assets). This asset benefit per unit of housing is equal to the difference between the rate of taxation on business capital income and that on the implicit rental income multiplied by the interest rate. $\left(\tau_{y}-\tau_{i r}\right) i$.

The term inside the second square brackets of (11) is also non negative. and it is strictly greater than zero if mortgage interest payments are not fully deductible. There is thus a borrowing penalty associated with mortgages unless the tax code allows full mortgage interest deductibility. The borrowing penalty can be written as $\tau_{y j}\left(1-\tau_{n}\right) i b$.

Letting $\phi$ represent the equity fraction held in the house. i.e. $\phi=(h-b) / h$. the net benefit from homeownership can be re-written as

$$
\pi(h . b: \omega)=\left[\left(\tau_{y} \tau_{m}-\tau_{i r}\right)+\phi \tau_{y}\left(1-\tau_{m}\right)\right] \cdot i \cdot h
$$

Since the rate of mortgage interest deductibility is assumed to be no less than the "normal" rate $\left(\tau_{m} \geq \tau_{i r} / \tau_{y}\right)$, the first term inside the square brackets is positive if the implicit rental 
income is taxed at a rate no greater than other types of income. The second term is always positive. ${ }^{11}$ It must therefore be the case that: ${ }^{12}$

Result 1. For individuals with sufficient savings, owning is strictly preferred to renting as long as the tax rate on implicit income is lower than that on other income $\left(\tau_{y}>\tau_{i r} \geq 0\right)$.

Using the first order conditions from the intra-temporal problem, it is straightforward to show that this net homeownership benefit translates into higher consumption of housing services and/or consumption goods.

Equation (12) also implies that the net benefit from homeownership is strictly increasing in the equity fraction of the house when mortgage interest payments are not fully deductible. When mortgage interest payments are fully deductible. the equity fraction does not alter the homeownership benefit. This is stated in the next result:

Result 2. For individuals with sufficient savings: (i) equity is strictly preferred to debt when mortgage interest payments are not fully deductible $\left(0 \leq \tau_{m}<1\right)$ and (ii) equity is equivalent to debt when mortgage interest payments are fully deductible $\left(\tau_{m}=1\right)$.

Under full mortgage interest deductibility, the net benefit from homeownership is independent of the equity fraction held in the house. Since the asset benefit is also independent of the equity fraction. full mortgage interest deductibility allows individuals with lower wealth to receive the same benefit from homeownership as wealthy individuals. This is generally the sense in which mortgage interest deductibility is perceived to have distribu-

\footnotetext{
${ }^{11}$ Unless mortgage interest payments are fully deductible. the second term is strictly greater than zero since the equity fraction is bounded away from zero by the downpayment constraint.

${ }^{12}$ If the extent of mortgage interest deductibility were less than the normal one - a case I ruled out in the specification of the tax structure - then the net benefit could become negative when imputed rents are taxed. As an example. consider the extreme case in which imputed rents are taxed at the same rate as other capital income and mortgage interest payments are not deductible. In this case. the revenue and opportunity cost of housing cancel out. resulting in a zero asset benefit. But any amount of borrowing will result in a penalty, thereby producing a negative net benefit from homeownership. In this case. non-negative benefits can only be obtained if no borrowing is needed - i.e. with 100 percent equity in the house.
} 
tional effect. These results suggest, however, that the lack of taxation of imputed rents rather than mortgage interest deductibility - should be regarded as a determining factor in explaining the homeownership rate.

\subsection{The Savings Decision}

As noted above, when the tax system makes owning a better alternative than renting, it artificially introduces a wedge between the after-tax rate of return on owner-occupied housing and that on other assets. Individuals can thus increase their return on savings by acquiring housing capital. Specifically, the after-tax return on savings for a given house size and mortgage is

$$
R(y ; h, b)=\frac{\left(1-\tau_{i r}\right) i h+\left(1-\tau_{y}\right) i a-\left(1-\tau_{y} \tau_{m}\right) i b}{y}
$$

When an individual's net worth is insufficient to cover the required downpayment, savings are solely composed of financial assets which carry a return equal to the after-tax rate of interest $\left(1-\tau_{y}\right) i$. Figure 1 shows that when imputed rents are not taxed and mortgage interest payments are deductible. an individual in this situation has a strong incentive to accumulate more wealth. Saving more today will eventually allow this individual to afford owning and benefit from the higher return provided by owner-occupied housing. The presence of increasing returns to wealth accumulation induces individuals to distort their savings decision by substituting consumption when young for future consumption.

The preferential tax trcatment of housing also induces individuals to own larger houses. From the definition of $R(y ; h . b)$. if $\tau_{i r}<\tau_{y}$, then the return on savings is increasing in $h$. This feature is illustrated Figure 1 which displays the return on savings as net worth increases for two house sizes. Conditional on net worth being sufficient to cover the downpayment on a larger house. an individual can increase the return on savings by moving 


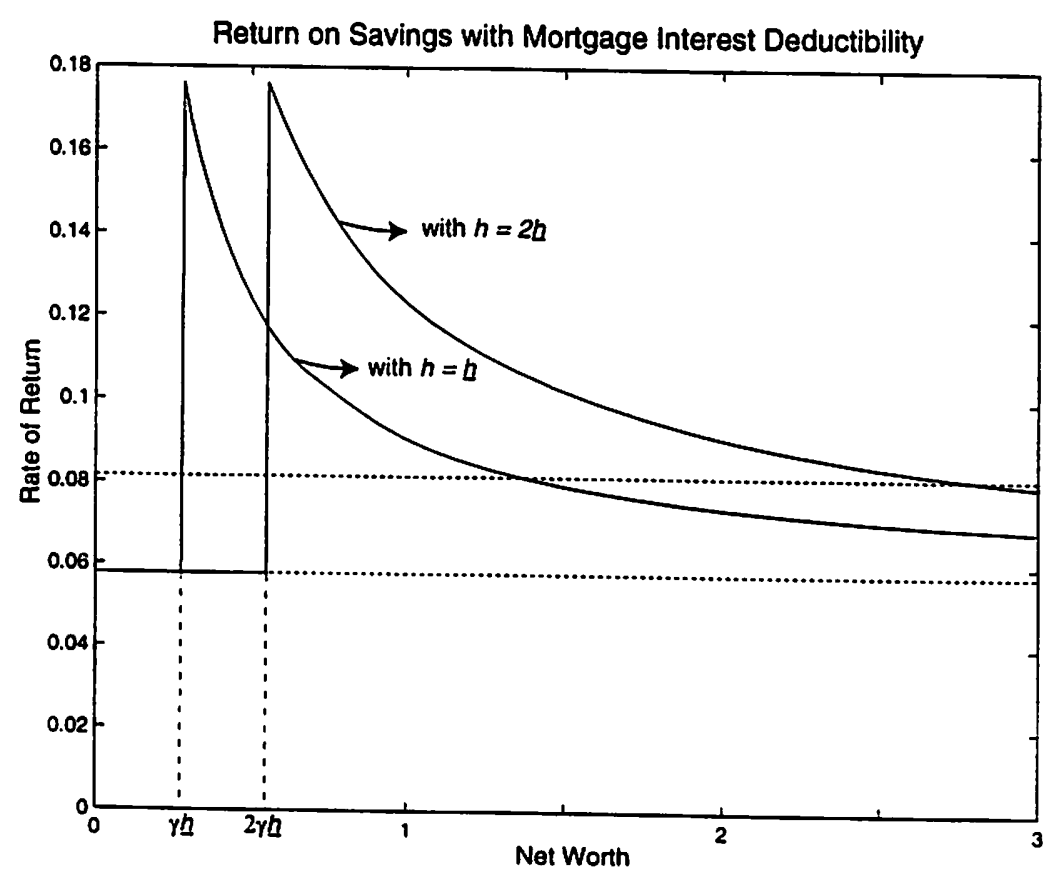

Figure 1: Rate of return on savings for $h=\{\underline{h}, 2 \underline{h}\}$ when imputed rents are not taxed $\left(\tau_{i r}=0\right)$ and mortgage interest payments are fully deductible $\left(\tau_{m}=1\right)$. The horizontal grid lines represent before- and after-tax interest rates (from the benchmark economy). The downpayment fraction is set at 20 percent.

into such a house. ${ }^{13}$ Of course. since housing constitutes both an asset and a consumption good (service), individuals will not simply choose house size to maximize the after-tax rate of return. Nonetheless. homeowners have an incentive to over-consume housing services as a result of the wedge between the rates of return on owner-occupied housing and financial assets.

Figure 2 shows that the size of the wedge between the two rates of return is significantly

\footnotetext{
${ }^{13}$ It is interesting to note that the return is bounded above because of the downpayment requirement. For any amount of savings greater or equal to the downpayment on the smallest possible house. this upper bound is reached by choosing the largest house an individual's current net worth can afford. that is. by setting $h=y / \gamma$. For any $y \geq \gamma \underline{h}$, this upper bound is in general given by$$
\bar{R}=\frac{\left(1-\tau_{1 r}\right) i-\left(1-\tau_{y} \tau_{m}\right) i(1-\gamma)}{\gamma},
$$

which is independent of the size of the house. This upper bound is increasing in the extent of mortgage interest deductibility $\left(\tau_{i n}\right)$ and decreasing in the rate of taxation on inputed rents $\left(\tau_{i r}\right)$.
} 
reduced when mortgage interest payments are not deductible. The return on savings in that figure assumes an optimal size of mortgage, which without mortgage deductibility involves minimizing the size of the mortgage. ${ }^{14}$ Individuals thus hold no financial assets until their mortgage has been fully paid. The return on savings in this case goes through three stages. First, before an individual can afford the downpayment, savings are only composed of financial assets which carry the after-tax rate of interest rate $\left(1-\tau_{y}\right) i$. Second, from the time of purchase until net worth exceeds the value of the house, the return on savings is equal to the interest rate $i$ since housing equity is not taxed. finally, when net worth exceeds the value of the house, the return on savings is a weighted average of the return on housing equity and that on financial assets.

Although the return on savings still takes a discrete jump once an individual becomes a homeowner, the size of the jump is small relative to the case in which mortgage interest payments are fully deductible. While the incentive to become a homeowner is still present. the incentive to accumulate savings when young is considerably reduced. The incentive for homeowners to over-consume housing services, however, is still strong.

When imputed rents are taxed at the same rate as other income, the return on savings is constant and equals the after-tax rate of interest. Taxing imputed rents thus eliminates the incentive to become a homeowner as well as the incentive to over-consume housing services. The welfare and distributional effects of these artificial incentives ultimately depends on individuals relative burden of housing tax provisions in addition to the parameters of the model. Calibrating these parameters is the object of the next section.

\footnotetext{
"This follows from Result 2 above. The size of the mortgage is set equal to $\max \{h-y .0\}$ for $y \geq \gamma \underline{h}$. With mortgage interest deductibility, the rate of return is independent of the mortgage size (a smaller mortgage means more financial assets and both carry the same after-tax rate of interest).
} 


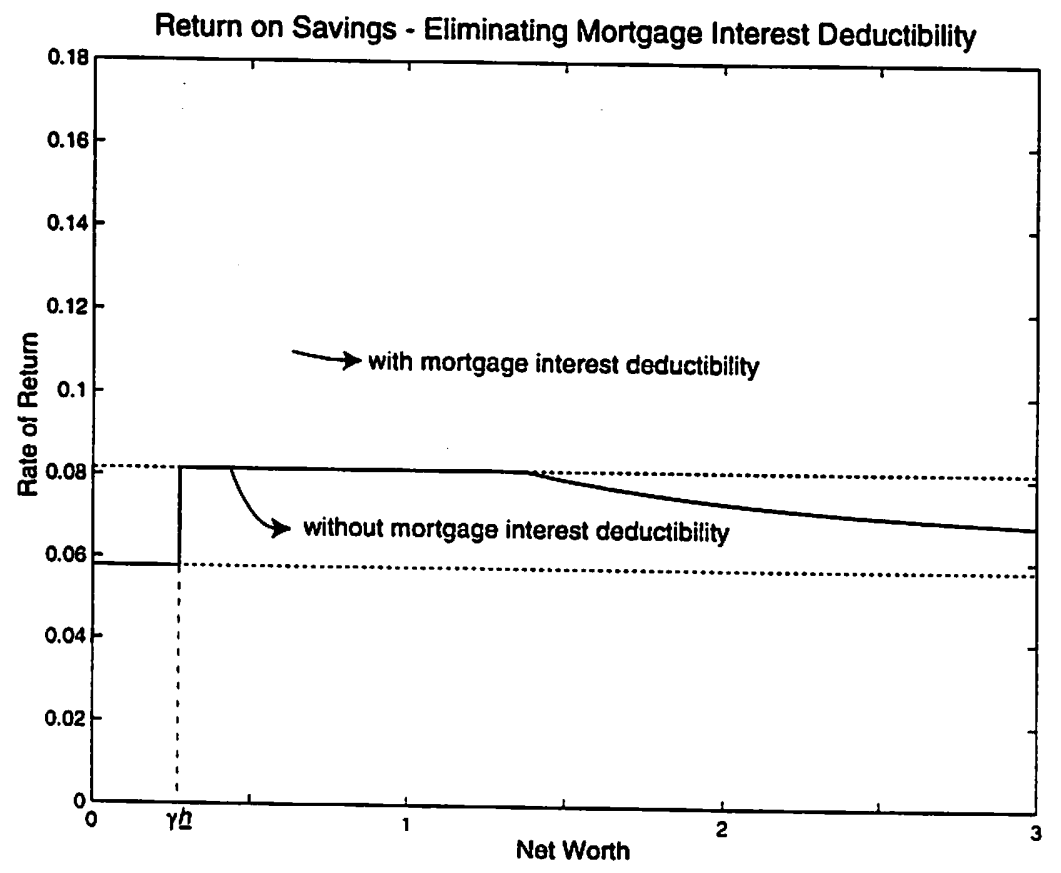

Figure 2: Rate of return on savings for $h=\underline{h}$ when imputed rents are not taxed $\left(\tau_{i r}=0\right)$, with and without mortgage interest deductibility. The horizontal grid lines represent beforeand after-tax interest rates (from the benchmark economy). The downpayment fraction is set at 20 percent.

\section{Calibration of the Benchmark Model}

The benchmark model is calibrated to the U.S. economy. In particular. imputed rents are not taxed and mortgage interest payments are fully deductible. The calibration exercise involves parameters associated with preferences $(\beta, \theta)$. technology $\left(A . \alpha . \underline{h}: M . \delta_{k}, \dot{\delta}_{h}\right)$, the tax system $\left(\tau_{y}, \tau_{i r} . \tau_{m}\right)$, as well as the downpayment fraction $(\gamma)$. The distribution of productivity levels within and across generations also needs to be specified. The values used are listed in Table 2 and statistics for the benchmark economy are reported in the second column of Table 3.

Demographics A model-period is taken to correspond to one full year. Individuals are assumed to live for $J=52$ model-periods. One can think of members of a new generation 
Table 2: Model Parameters

\begin{tabular}{lcl}
\hline \hline Preferences & $\beta$ & 0.964 \\
Technology & $\theta$ & 0.55 \\
& $A$ & 1.078 \\
& $\alpha$ & 0.29 \\
& $\underline{h}$ & 1.38 \\
& $\delta_{k}$ & 2 \\
& $\delta_{h}$ & 0.0809 \\
Tax System & $\tau_{y}$ & 0.0634 \\
& $\tau_{m}$ & 1 \\
& $\tau_{i r}$ & 0 \\
Downpayment & $\gamma$ & 0.2 \\
\hline \hline
\end{tabular}

as being born at real-life age 24 (model-period one) and having an expected age of death of 75 years (52 model-periods). The retirement age is set at age 63 (model-period 40 ).

Preferences The value of the discount factor is chosen to make the capital-output ratio equal to 3.0. It should be noted that capital refers to the total amount of capital. which includes housing and business capital. and that output corresponds to the sum of output goods and the value of housing services. The discount factor which achieves the desired capital-output ratio is 0.964 .

The share of housing services in total expenditures is controlled by $\theta$. I set this parameter in order to replicate the share of housing capital in total capital in the U.S. economy over the 1959-1989 period. A value of 0.55 for $\theta$ achieved a share of housing capital of 54.7 percent in the model. which is the value found in the data. ${ }^{15}$ One implication of this parameter is that in a convex model. the share of housing services in total expenditures is equal to 35.5 percent $(\theta /(1+\theta))$. The non-convexities introduced by the minimum size of houses and the downpayment induce some households to consume more or less housing services than they

\footnotetext{
${ }^{15}$ The data is taken from Fixed Reproducible Tangible Wealth published be the Department of Commerce (1993).
} 
would in a convex model. In the benchmark model, the share of housing services in total consumption is approximately 40 percent. This share is considerably higher than the 29 percent suggested by Skinner (1996), reflecting the fact that my definition of housing capital includes both houses and consumer durables. This broad definition of housing capital is motivated by the U.S. tax system. Prior to the 1986 tax reform, there were virtually no distinctions between the tax treatment of consumer durables and housing. Although the 1986 tax reform eliminated the deduction of interest payments for consumer durables, households have been contracting bigger mortgages in order to finance their purchases of consumer durables. ${ }^{16}$ This evidence suggests that the definition of housing capital should indeed include consumer durables.

Downpayment Jappelli and Pagano (1994) report that the maximum loan-to-value ratio in the U.S. was 80 percent from 1961 to 1980 , and 89 percent from 1981 to 1987. Based on these figures, I set the downpayment fraction equal to 20 percent in the benchmark model.

Technology The technology level $(A=1.078)$ is such that the wage rate is unity when the capital output ratio is equal to three. To compute the business capital share of output in the data which corresponds to that in the model. the service flow attributed to housing capital has to be subtracted from total output. Doing so. Greenwood. Rogerson and Wright (1995) calculated a value of $\alpha$ equal to 0.29 .

The minimum size house and the maximum number of roommates are such that the share of housing services in total expenditures for the poorest quintile is approximately 50 percent and the homeownership rate is about 74 percent. $^{17}$ With two roommates and a minimum size house equal to $1.38(\underline{h} / Y=0.995)$. given a downpayment fraction of 20

\footnotetext{
${ }^{16}$ This is documented in Feenberg and Skinner (1990) and Jappelli and Pagano (1989).

${ }^{17}$ The homeownership rate corresponds to that found in the data (CPS) used to calibrate the labor income distribution. The share of housing services in total expenditures for the lowest quintile is taken from the Survey of Consumer Expenditures. 1993.
} 
percent, the model replicates both statistics.

The depreciation rates are set to match the average depreciation of constant-cost valued (\$1987) net stock of residential and business capital over the 1959-1989 period. I calculated depreciation rates of 6.34 and 8.09 percent for residential and business capital respectively. ${ }^{18}$ The depreciation rate for business capital is a weighted average of the depreciation of business structures and producer durables. For residential capital, it is a weighted average of housing and consumer durables.

Tax System The tax system in the benchmark model is such that imputed rents are not taxed $\left(\tau_{i r}=0\right)$ and mortgage interest payments are fully deductible $\left(\tau_{m}=1\right)$. The other parameter of the tax system, the rate of income taxation $\left(\tau_{y}=0.294\right)$, is set to make the ratio of government expenditures to GDP equal to 19.5 percent.

Labor Income Distribution The distribution of productivity levels directly controls the labor endowment process and thus labor income. I calibrate this process using the CPS data for the year 1994. More precisely, I calculated the mean labor income for each quintile in the data at each age and assigned that number directly to the five individuals making up the population in the model. ${ }^{19}$ The (normalized) labor income profile for each individual each representing a quintile - is shown in Figure 3.

The retirement age is obtained using the same data. The median labor income for the entire male population becomes zero at age 63 (model age 40 ). which is used as the retirement age in the model.

\footnotetext{
${ }^{18}$ The data is taken from Fixed Reproducible Tangible Wealth published be the Department of Commerce (1993).

${ }^{19}$ I only used males who's labor income was positive and who paid for their housing services during that year.
} 


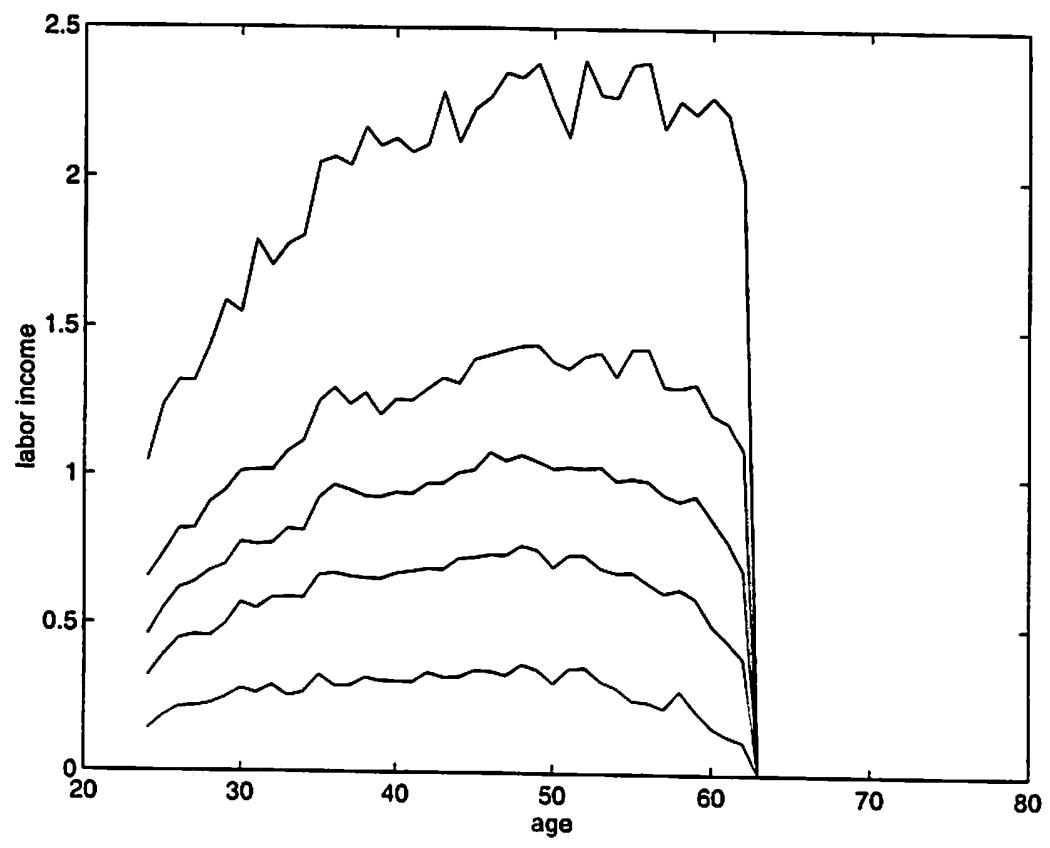

Figure 3: Labor income process for each quintile.

\section{Experiments}

In this section, two experiments are carried out in order to quantify the impact of mortgage interest deductibility and the lack of taxation of imputed rents on general equilibrium quantities. Each experiment is revenue-neutral in the sense that government revenues are assumed to remain constant across fiscal policy arrangements. Statistics for each experiment are reported in Table 3 along with the quantities obtained in the benchmark model. Before discussing the results. a measure of welfare needs to be defined.

\subsection{Measure of Welfare}

The measure of welfare or average utility for a given fiscal policy arrangement $\omega=\left\{\tau_{y}, \tau_{i r}, \tau_{m}\right\} \in$ $\Omega$ is defined as the expected utility level of a newly born individual prior to having any knowledge about his/her productivity level process. This utility level. denoted $W(\omega)$, is given by 
Table 3: Statistics for the benchmark model and the two experiments.

\begin{tabular}{lccc}
\hline \hline & $\begin{array}{c}\text { Benchmark } \\
\text { Model }\end{array}$ & $\begin{array}{c}\text { Experiment 1 } \\
\left(\tau_{m}=0\right)\end{array}$ & $\begin{array}{c}\text { Experiment 2 } \\
\left(\tau_{\text {ir }}=\tau_{y}\right)\end{array}$ \\
\hline Quantities & & & \\
Total Output $(Y)$ & 1.386 & 1.387 & 1.363 \\
Total Capital & 4.161 & 4.229 & 4.092 \\
Business Capital $(K)$ & 1.883 & 1.958 & 2.008 \\
Total Housing & 2.278 & 2.271 & 2.083 \\
Owner Housing $(H)$ & 2.087 & 2.024 & 1.620 \\
Rental Housing $\left(H^{f}\right)$ & 0.191 & 0.248 & 0.463 \\
Relative Quantities & & & \\
Total Capital $/ Y$ & 3.000 & 3.048 & 3.002 \\
$K /($ Total Capital) & 0.453 & 0.463 & 0.491 \\
$H /\left(H+H^{f}\right)$ & 0.916 & 0.891 & 0.778 \\
$G / Y$ & 0.195 & 0.195 & 0.198 \\
$(C+p X) / Y$ & 0.591 & 0.587 & 0.586 \\
$p X /(p X+C)$ & 0.403 & 0.392 & 0.360 \\
Prices & & & \\
$i(\%)$ & 8.173 & 7.722 & 7.444 \\
$w$ & 1.000 & 1.011 & 1.018 \\
$P$ & 0.145 & 0.141 & 0.138 \\
Homeownership Rate & 0.742 & 0.700 & {$[0.0 .569]$} \\
Income Tax Rate $\left(\tau_{y}\right)$ & 0.294 & 0.288 & 0.253 \\
\hline \hline
\end{tabular}

$$
W(\omega) \equiv \sum_{j=1}^{J} \int \beta^{j-1} u\left[c_{j}\left(y_{j}: z_{j}\right) \cdot x_{j}\left(y_{j}: z_{j}\right)\right] d \lambda_{j}\left(y_{j}: z_{j}\right) .
$$

where $\lambda_{j}\left(y_{j} ; z_{j}\right)$ is an age-specific measure of agent types. To compare welfare across policy arrangements, the difference in welfare between two policy arrangements is defined as the amount of consumption. as a percentage of average life-time consumption $\bar{c}$. that needs to be given to an (unborn) individual every period as a compensation to make the new born individual indifferent between the two policy arrangements. Omitting the arguments in the 
policy rules for consumption of goods and housing services, it is defined as the value of $\kappa$ such that

$$
W\left(\omega_{1}\right)=W\left(\omega_{2}, \kappa\right)=\sum_{j=1}^{J} \int \beta^{j-1} u\left[\left(c_{j}+\kappa \cdot \bar{c}\right), x_{j}\right] d \lambda_{j}\left(y_{j} ; z_{j}\right)
$$

The same measure is used to compare fiscal policy arrangements for specific individuals, except of course that there is no need to integrate over individuals.

\subsection{Experiment 1: Removing Mortgage Interest Deductibility}

This experiment consists of eliminating mortgage interest deductibility by setting the parameter which controls the degree of mortgage interest deductibility equal to zero $\left(\tau_{m}=0\right)$. To preserve comparability across tax systems, the income tax rate $\left(\tau_{y}\right)$ is adjusted to maintain the level of government expenditures at the level found in the benchmark model. The results from this experiment appear in the third column of Table 3. The findings are discussed in terms of aggregate quantities, focussing mainly on capital stocks. followed by welfare and distributional effects.

Aggregate Quantities Removing mortgage interest deductibility has no noticeable impact on the size of housing capital. The composition of housing capital. however. changes as rental housing increases at the expense of owner-occupied housing. In the process. the homeownership rate drops 4.2 percentage points.

These findings can be explained in light of the discussion in section 3. Since imputed rents remain untaxed. owning remains a better alternative to renting as long as the downpayment constraint and the minimum size house do not bind. The relative advantage of owning versus renting, however. is smaller than in the benchmark model. This smaller net benefit from homeownership reduces the difference between the rate of return on fi- 
nancial assets relative to that on owner-occupied housing when an individual becomes a homeowner. Accordingly, individuals are not as willing to sacrifice consumption in early periods in order to reach the point at which they benefit from owner-occupying their home. Individuals postpone the purchase of their first house by 2 to 5 years, resulting in a lower owner-occupied housing stock and homeownership rate, as well as a higher stock of rental housing.

Individuals are obviously not as inclined to borrow against their house without mortgage interest deductibility. As illustrated in section 3, equity is now strictly preferred to debt as the benefit from homeownership only come from the equity fraction. As a result, individuals have on average smaller mortgages and repay them faster than in the benchmark model. The aggregate loan-to-value ratio falls from 12.3 percent to 6.8 percent, a 45 percent drop. The average number of years individuals take to pay back their mortgage falls from 12 to 7 years.

The stock of business capital increases by approximately 4 percent relative to the benchmark level. This is a direct consequence of the revenue-neutral nature of the experiment. Since the government no longer needs to bear the costs associated with mortgage interest deductibility; a lower tax rate (2.2 percent lower) is needed in order for government revenues to remain at the benchmark level. The extra desire to save generated by the higher disposable income translates into a lower interest rate. and thus a higher stock of business capital.

Welfare Effects Welfare results for each quintile appear in Table 4. The interpretation of these numbers is as follows: to make the first individual (who represents the first quintile of the labor income distribution) indifferent between the tax system of the benchmark model and that of experiment 1. a per period compensation representing 5.22 percent of his/her average life-time consumption in the benchmark model would be required. For an unborn individual. this number is equal to 1.08 percent of expected life-time consumption. 
Table 4: Welfare comparisons between the benchmark model and experiment 1.

\begin{tabular}{lc}
\hline \hline & $\begin{array}{c}\text { Consumption } \\
\text { Compensation (\%) }\end{array}$ \\
\hline First Quintile & 5.22 \\
Second Quintile & 1.57 \\
Third Quintile & 1.05 \\
Fourth Quintile & 0.98 \\
Fifth Quintile & 0.85 \\
\hline \hline
\end{tabular}

The fact that the poorest individual prefers the tax system of experiment 1 is not surprising: the representative individual of the first quintile never owns and so never benefits from mortgage interest deductibility in the first place. What is more surprising is that all individuals would rather live in a world in which mortgage interest payments are not deductible, including those who own houses and benefit from mortgage interest deductibility in the benchmark model.

Underlying this result is the steepness of individuals: consumption profiles. In the benchmark model, individuals strive to accumulate the downpayment as quickly as possible to become homeowners. By curtailing this desire to become homeowners, the elimination of mortgage interest deductibility allows individuals to better smooth consumption in the first few periods of their lives. making their consumption profile less steep than in the benchmark model. For some individuals. this criteria outweighs the fact that their average life-time consumption of both goods actually falls relative to their benchmark allocation.

Distributional Effects The fact that all individuals prefer doing away with mortgage interest deductibility suggests that re-distributional effects of eliminating this program are small. One measure of wealth concentration is the GINI coefficient. From the benchmark model to experiment 1. the wealth GINI coefficient falls by less than 1 percent (from 54.52 to 54.02 percent), also suggesting that the re-distributional impact of the elimination of this tax provision is very small. The same conclusion is reached in terms of inter-generational effects. 
The reason for this very small re-distributional impact is twofold: first, mortgage interest deductions represent a small fraction of an individual's total tax burden; second, only the first few periods are significantly affected by the change in the tax system. Furthermore, the amount of net worth does not differ drastically from one system to the next even during those first few periods since a large fraction of the owner-occupied housing stock in the benchmark model is held in the form of debt, thus not contributing to individuals' net wealth.

\subsection{Experiment 2: Taxing Imputed Rents}

This experiment consists of setting the rate of taxation on implicit rental income equal to the rate of taxation on other income $\left(\tau_{i r}=\tau_{y}\right)$. The new rate of taxation is then adjusted to maintain government expenditures at the level found in the benchmark model. ${ }^{20}$ The results from this experiment appear in the fourth column of Table 3. As for experiment 1 , the findings are discussed in terms of aggregate quantities, welfare and distributional effects.

Aggregate Quantities It is clear from Table 3 that the failure to tax imputed rents has a large impact on both stocks of capital: business capital is 6.64 percent higher than in the benchmark model and housing 8.56 percent lower. This suggest a very important crowding out effect of business capital due to preferential tax treatment of housing.

The homeownership rate is not well defined in the context of experiment 2 since no individual strictly prefers owning to renting. Nevertheless. assuming that every indifferent individual chooses to own. only 56.9 percent of the population are homeowners relative to 74.2 in the benchmark model. An interpretation of this statistic is that 23.3 percent of homeowners in the benchmark model own because of the tax code.

\footnotetext{
${ }^{20}$ The extent of mortgage interest deductibility has to be equal to one in order for individuals to at least
receive a normal deduction.
} 
The revenues lost by the government due to the failure to tax the service income from owner-occupied housing amount to 18.55 percent of total (net) taxes paid by individuals in the benchmark model. Taxing imputed rents at the same rate as other income allows the government to cut the income tax rate by over 11 percent, substantially increasing individuals' disposable income. This increases individuals' desire to save, which translates into a lower interest rate and a higher stock of business capital. More importantly, the tax code no longer creates artificial increasing returns to wealth accumulation since the rates of return on owner-occupied housing and business capital are the same when all sources of capital income are taxed at the same rate. Individuals thus dispose of their income in a more unhindered fashion. In particular, the housing services share of total expenditures is now equal to 35.5 percent for most individuals, which corresponds to the share that would obtain in a convex model. ${ }^{21}$

Welfare Effects Welfare results are presented in Table 5, where the second column indicates the welfare gains for each quintile as we move from the benchmark model to the tax system of experiment 2 , and the third column indicates the welfare gains as we move from the tax system of experiment 1 to that of experiment 2 . As in the previous experiment. the conclusion is straightforward since all individuals are better off when all sources of income are taxed at the same rate. An unborn individual would require expected consumption in every period to be higher by 3.97 percent of the benchmark model's average expected life-time consumption to be indifferent between the two tax systems.

Underlying these findings is that taxing imputed rents eliminates the wedge between the returns on owner-occupied housing and other assets (see Figure 4). As a result. individuals no longer have an incentive to excessively accumulate savings when young, nor do they tend to over-invest in housing capital. Their consumption profiles are thus much flatter under

\footnotetext{
${ }^{21}$ The poorest individual is still constrained by the smallest size of rental units and thus spend more than 35.5 percent on housing services.
} 

Table 5: Welfare comparisons between the benchmark model, experiment 1 and experi-
ment 2 .

\begin{tabular}{lcc}
\hline \hline & $\begin{array}{c}\text { Consumption } \\
\text { Compensation (\%) } \\
\text { vs Benchmark }\end{array}$ & $\begin{array}{c}\text { Consumption } \\
\text { Compensation (\%) } \\
\text { vs Experiment 1 }\end{array}$ \\
\hline First Quintile & 16.58 & 11.01 \\
Second Quintile & 5.76 & 4.17 \\
Third Quintile & 4.36 & 3.32 \\
Fourth Quintile & 4.20 & 3.23 \\
Fifth Quintile & 4.13 & 2.26 \\
\hline \hline
\end{tabular}

this tax system than under the benchmark tax specification (see Figure 5).

Distributional Effects The wealth GINI coefficient in experiment 2 is 2.2 percent higher than in the benchmark model. Combined with the welfare results, this means that given the choice between the benchmark tax specification and that of experiment 2 , every individual would rather live in a world in which wealth is more concentrated among rich individuals. Since most individuals with relatively low net worth are young individuals who's income profiles are rising over time, a re-distribution of wealth from poor. young individuals to wealthier, older individuals is welfare improving.

\subsection{A Note on Transitional Dynamics}

In interpreting the findings from the above experiments. one has to consider the impact transitional dynamics may have on the results. Since the stock of business capital increases in both experiments. one would a priori expect the reported welfare gains to be overstated. ${ }^{22}$ This is only partially correct in this study since one has to consider the total stock of capital as opposed to business capital alone. In the first experiment. the aggregate stock of capital increases by 1.6 percent. As a result. some individuals from initial generations will likely

\footnotetext{
${ }^{22}$ The usual argument is that savings have to increase in order for the stock of business capital to increase. which means lower consumption during the transition to the new steady state.
} 


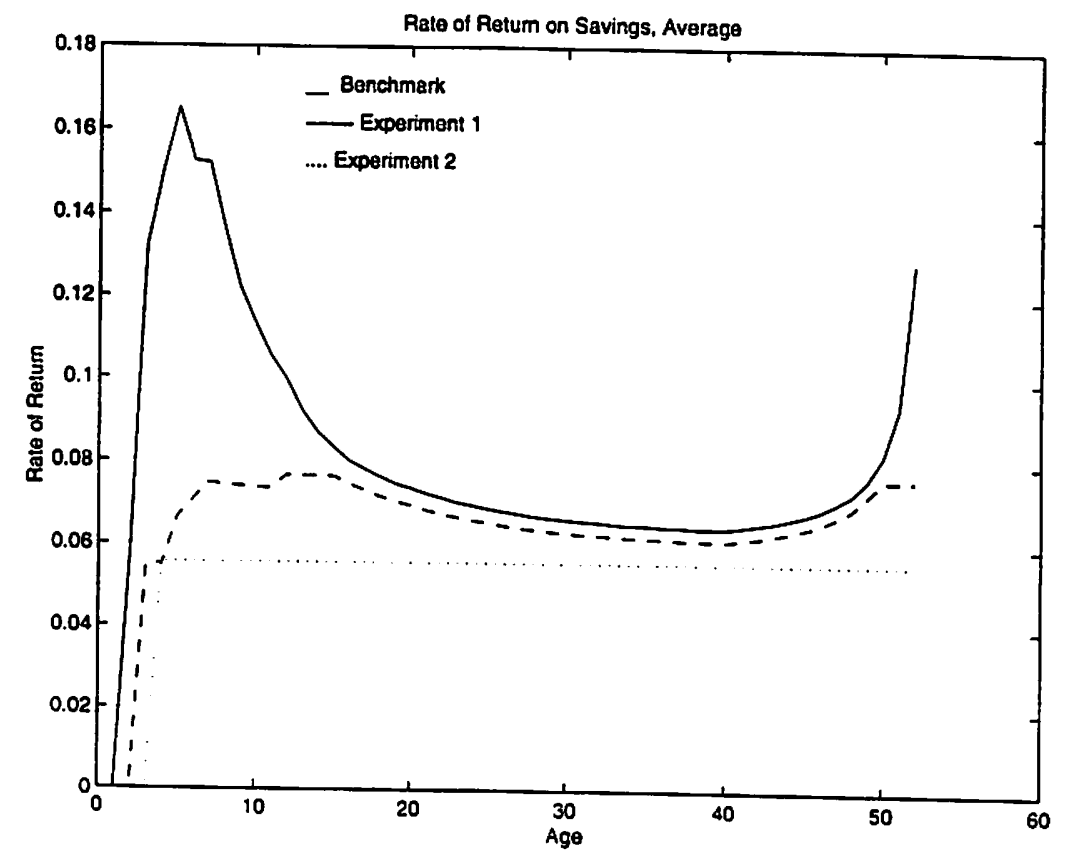

Figure 4: Return on savings for the average individual at each age in the benchmark model, experiment 1 and experiment 2.

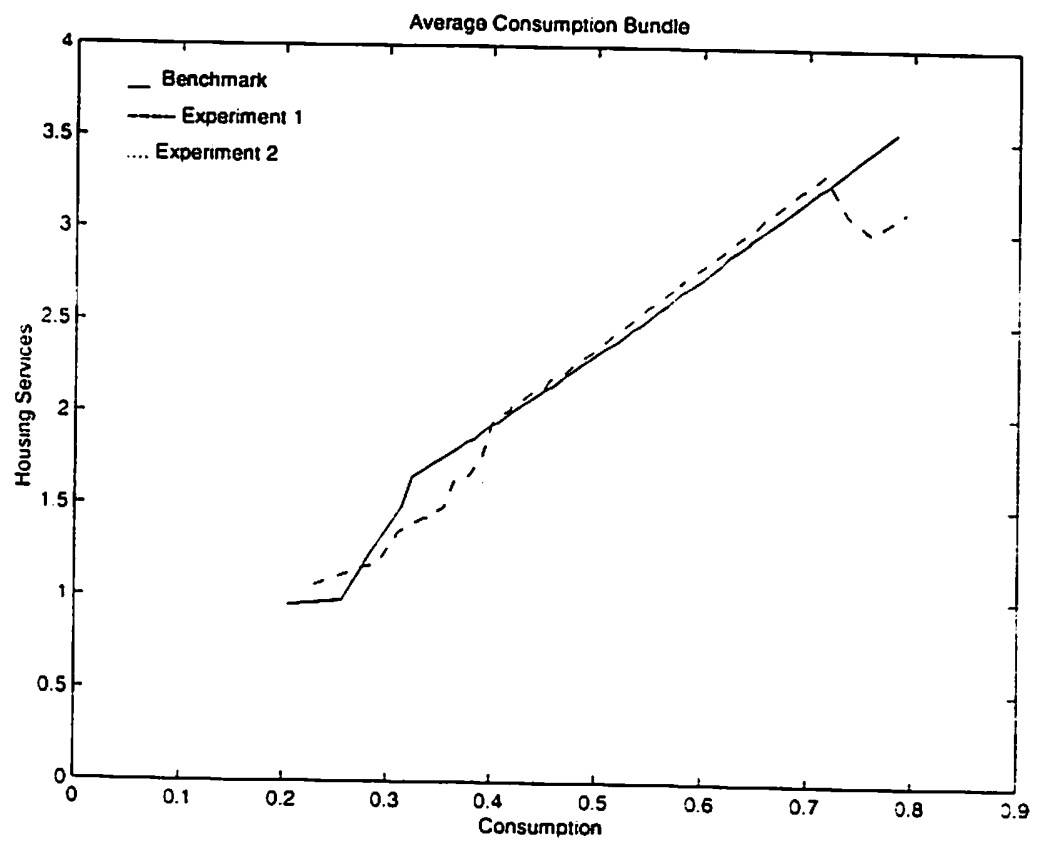

Figure 5: Evolution of the average consumption bundle over the life-time of individuals in the benchmark model. experiment 1 and experiment 2 . 
incur welfare losses once mortgage interest deductibility is eliminated. Individuals most likely to suffer from this change in fiscal policy are older people from initial generations. First, these individuals will not benefit from the lower rate of taxation on labor income since they are already retired. Second, they will be facing a lower after-tax rate of interest at a time when their only income takes the form of interest income. Finally, they may find themselves with much larger houses than warranted by the new tax code since they can no longer freely mortgage their house to finance consumption during the last few periods of their lives.

In the second experiment, transitional dynamics may actually increase total welfare gains. This is because the aggregate stock of capital will be decreasing during the transition period. Under perfect reversibility, a large fraction of the stock of housing capital would simply be transformed into business capital immediately following the change in fiscal policy.

\section{Conclusion}

This paper explores the impact of the two most important housing tax provisions currently in place in the U.S. tax code. namely the failure to tax imputed rents and mortgage interest deductibility. This study stresses that the interaction between the tenure choice and the tax code is an essential channel through which housing tax provisions distort individuals: decisions. Explicitly modeling the tenure decision is thus crucial to understand the impact of the preferential tax treatment of housing which characterizes the current tax code. Simulations suggest that either taxing imputed rents or disallowing mortgage interest deductions translates into substantial welfare gains. Furthermore, these gains accrue to individuals across the labor income distribution. Distributional effects are found to be much smaller than is generally believed. Studying optimal taxation in a similar framework constitutes an interesting avenue for future research. 


\section{Appendix: Definition of a Competitive Equilibrium}

A steady state competitive equilibrium for a given set of policy arrangements $\Omega=\left\{\tau_{y}, \tau_{i r}, \tau_{m}\right\}=$ consists of a collection of value functions $V_{j}\left(y_{j} ; z_{j}\right)$ and individual decision rules $c_{j}\left(y_{j} ; z_{j}\right)$, $x_{j}\left(y_{j} ; z_{j}\right), a_{j}\left(y_{j} ; z_{j}\right), h_{j}\left(y_{j} ; z_{j}\right), b_{j}\left(y_{j} ; z_{j}\right)$ for each age $j=1,2, \ldots, J$, an age-dependant but time-invariant measure of agent types $\lambda_{j}\left(y_{j} ; z_{j}\right)$, a set of relative prices $\{p, i, w\}$, and aggregate quantities $\left\{G, Y, K, N, D^{f}, B^{f}, H^{f}, S^{f}\right\}$ such that

1. given prices and the fiscal policy, individual decision rules solve the dynamic program given by (1)-(7);

2. inputs are priced competitively,

$$
w=f_{2}(K, N) \text { and } i=f_{1}(K, N)-\delta_{k} \text {; }
$$

3. given prices and the fiscal policy, $\left\{D^{f}, B^{f}, H^{f}, S^{f}\right\}$ solves the financial institutions: problem given by (8)-(9);

4. the government maintains a balanced budget every period.

$$
G=\sum_{j=1}^{J} \int_{\lambda_{j}}\left[\tau_{y} z_{j} w+\tau_{y} i a\left(y_{j} ; z_{j}\right)+\tau_{i r} i h\left(y_{j} ; z_{j}\right)-\tau_{y} \tau_{m} i b\left(y_{j}: z_{j}\right)\right] d \lambda_{j}\left(y_{j}: z_{j}\right)
$$

5. Markets clear:

i. asset markets clear:

$$
\begin{aligned}
& K=\sum_{j=1}^{J} \int_{\lambda_{j}}\left[a\left(y_{j} ; z_{j}\right)-b\left(y_{j} ; z_{j}\right)\right] d \lambda_{j}\left(y_{j} ; z_{j}\right)-H^{f} . \\
& D^{f}=\sum_{j=1}^{J} \int_{\lambda_{j}} a\left(y_{j}: z_{j}\right) d \lambda_{j}\left(y_{j} ; z_{j}\right)-K . \\
& B^{f}=\sum_{j=1}^{J} \int_{\lambda_{j}} b\left(y_{j}: z_{j}\right) d \lambda_{j}\left(y_{j}: z_{j}\right):
\end{aligned}
$$

ii. the goods market clears:

$$
f(K . N)=\sum_{j=1}^{J} \int_{\lambda_{j}}\left[c\left(y_{j} ; z_{j}\right)+\dot{\delta}_{h} h\left(y_{j} ; z_{j}\right)\right] d \lambda_{j}\left(y_{j} ; z_{j}\right)+\dot{\delta}_{k} K+\dot{\delta}_{h} H^{f}+G
$$

iii. the rental market for housing services clears:

$$
\sum_{j=1}^{J} \int_{\lambda_{j}}\left[x\left(y_{j} ; z_{j}\right)-h\left(y_{j} ; z_{j}\right)\right] d \lambda_{j}\left(y_{j} ; z_{j}\right)=S^{f}=H^{f}:
$$


All but the asset market and rental housing market clearing conditions are standard. The first asset market clearing condition stipulates that the aggregate amount of financial assets (net of mortgages) which is not invested in housing capital by financial institutions must correspond to the aggregate stock of business capital in the economy. The second asset market clearing condition requires that the amount of deposits accepted by financial institutions be equal to the amount of financial assets held by individuals minus their holding of business capital equity. The last asset market clearing condition simply equates the amount of loans issued by financial institutions to the aggregate amount of mortgages outstanding. Finally, the rental market clearing condition says that the amount of housing services which is not owner-occupied must correspond to the amount of housing services rented out by financial institutions. 


\section{References}

[1] Artle, Roland and Varaiya, Pravin. "Life-Cycle Consumption and Homeownership." Journal of Economic Theory, Vol. 18 (1), June 1978.

[2] Auerbach, Alan J. and Kotlikoff, Laurence J. Dynamic Fiscal Policy. Cambridge: Cambridge University Press, 1987.

[3] Berkovec, James and Fullerton, Don. "A General Equilibrium Model of Housing, Taxes, and Portfolio Choice." Journal of Political Economy, Vol. 100 (2), April 1992.

[4] Díaz-Giménez, Javier. Prescott, Edward C., Fitzgerald, Terry and Alvarez, Fernando. "Banking in Computable General Equilibrium Economies." Journal of Economic Dynamics and Control. Vol. 16 (3/4), July/October 1992.

[5] Engelhardt. Gary V. "Consumption. Down Payments, and Liquidity Constraints." Journal of Money, Credit, and Banking, Vol. 28 (2), May 1996.

[6] Feldstein. Martin. -Inflation. Tax Rules and the Accumulation of Residential and Nonresidential Capital." Scandinavian Journal of Economics, Vol. 84 (2). 1982.

[7] Fullerton. Don. "The Indexation of Interest. Depreciation. and Capital Gains and Tax Reform in the United States." Journal of Public Economics. Vol. 32 (1). February 1987.

[8] Gahvari, Firouz. "Incidence and Efficiency Aspects of Differential Taxation of Residential and Industrial Capital in a Growing Economy." Journal of Public Economics. Vol. $25(1 / 2)$, November 1984.

[9] Greenwood. Jeremy. Rogerson. Richard and Wright. Randall. "Household Production in Real Business Cycle Theory," in Thomas F. Cooley, ed.. Frontiers of Business Cycle Research. Princeton: Princeton University Press. 1995. 
[10] Hendershott, Patric H. and Hu, Sheng Cheng. "The Allocation of Capital Between Residential and Nonresidential Uses: Taxes, Inflation and Capital Market Constraints." Journal of Finance, Vol. XXXVIII (3), June 1983.

[11] Henderson, J. Vernon and Ioannides, Yannis M. "A Model of Housing Tenure Choice." American Economic Review, Vol. 73 (1), March 1983.

[12] Jappelli, Tullio and Pagano, Marco. "Consumption and Capital Market Imperfections: An International Comparison." American Economic Review, Vol. 79 (5), December 1989.

[13] Jappelli, Tullio and Pagano, Marco. "Savings, Growth, and Liquidity Constraints." Quarterly Journal of Economics, Vol. CIX (1), February 1994.

[14] Laidler, David .E.W. "Income Tax Incentives for Owner-Occupied Housing," in A. Harberger and M. Bailey, eds.. The taxation of income from capital. Washington: The Brookings Institution, 1969.

[15] OECD. Taxation and Household Savings. Paris: OECD, 1994.

[16] Poterba. James M. “Tax Subsidies to Owner-Occupied Housing: An Asset Market Approach." Quarterly Journal of Economics. Vol. XCIX (4), November 1984.

[17] Poterba. James M. “Taxation and Housing Markets: Preliminary Evidence on the Effects of the Recent Tax Reform. in J. Slemrod. ed.. Do Taxes Matter? The Impact of the Tax Reform Act of 1986. Cambridge: The MIT Press. 1990.

[18] Poterba. James M. "Taxation and Housing: Old Questions, New Answers." American Economic Review. Vol. 82 (2). May 1992. 
[19] Rosen, Harvey S. "Housing Subsidies: Effects on Housing Decisions, Efficiency, and Equity," in M. Feldstein and A. Auerbach, eds., Handbook of Public Economics, Volume 1. Amsterdam: North Holland, 1985.

[20] Skinner, Jonathan. "The Dynamic Efficiency Cost of not Taxing Housing." Journal of Public Economics, Vol. 59 (3), March 1996.

[21] Skinner Jonathan and Feenberg, Daniel. "The Impact of the 1986 Tax Reform on Personal Saving," in J. Slemrod, ed., Do Taxes Matter? The Impact of the Tax Reform Act of 1986. Cambridge: The MIT Press, 1990.

[22] Stein, Jeremy C. "Prices and Trading Volume in the Housing Market: A Model with Downpayment Effects." Quarterly Journal of Economics, Vol. CX (2), May 1995.

[23] U.S. Bureau of Economic Analysis, Department of Commerce. Fixed Reproducible Tangible Wealth in the United States, 1925-93. Washington. DC: U.S. Government Printing Office, 1994. 